South Atlantic Modern Language Association

"Much Ado about Nothing" and the Spectator Author(s): William Babula

Source: South Atlantic Bulletin, Vol. 41, No. 1 (Jan., 1976), pp. 9-15

Published by: South Atlantic Modern Language Association 


\title{
"MUCH ADO ABOUT NOTHING" AND THE SPECTATOR
}

\author{
William Babula \\ University of Miami
}

In a foreword to a collection of essays entitled Reinterpretations of Elizabethan Drama, Norman Rabkin makes the following generalization about the contributors: ". . . all of them discuss the play as earlier critics neither could nor wanted to: the play as it impinges on its audience, as it is experienced." 1 That is what I am going to do in this essay: to discuss Much Ado about Nothing as it is experienced by an audience. Now Much Ado has been variously described. To cite only a few examples: it is concerned with the force of evil in a society that turns in on itself; ${ }^{2}$ with the truth of love; ${ }^{3}$ with the triumph of true wit and harmless folly over false wisdom. ${ }^{4}$ A pair of critics state flatly: "We hold that the theme of this comedy is honor." 5 But the statement of the theme is no substitute for the effect of the play on an audience. Much closer to our sense of the play, to the way we feel about it when we see it performed or read it is A. P. Rossiter's suggestion that the comedy as a whole concerns "misapprehension." 6 Perhaps even closer is the suggestion of another critic that the chief concern of the play is with a confusion that culminates in Beatrice's command, "Kill Claudio."7

Obviously there is misapprehension and confusion in Much Ado. Betrand Evans points out that there are eight "practices" or deceptions that keep everyone in the play misapprehending. ${ }^{8}$ But he also argues that the audience, from its high vantage point, is fully aware of all the "practices" and is thus never deceived. ${ }^{9} \mathrm{He}$ is right if only the plot line action is considered; we are in on every "practice." Our superior awareness provides a good deal of the comic fun of the play. But, I suggest, as we experience Much $A d o$ we do misapprehend, we do feel confused just as the characters on the stage do. We are not, of course, confused by the tricks the characters play on each other; we are confused and uncertain about things we may have thought ourselves long certain of.

For example, Paul A. Jorgensen has noted that Richard Grant White proposed over a century ago "that the original audience both pronounced and interpreted the title as Much Ado about Noting; for noting, or observing and eavesdropping, is found in almost every scene and is indispensable to all of the plots." 10 But what of this eavesdropping? We can say eavesdropping is wrong, but the play refuses to support this precise statement just as it 
refuses to support its opposite. Consider these instances of it in the play. Claudio spies on Hero and is tricked into believing that his Hero is "every man's Hero." Conversely, the prince and his companion plotters trick Benedick and Beatrice into overhearing certain statements that lead each to believe that he or she is loved by the other. The problem of who will be first to admit love is overcome by the device and the pair finally goes towards marriage. Because the incompetent Watch overhears Borachio bragging about his role in deceiving Claudio, Hero's name can finally be cleared. Shakespeare presents simultaneously the notions that eavesdropping is a socially positive and socially negative act. The dramatist is making generalization difficult.

As in most Elizabethan court comedies, the pun abounds in the court comedy plot of $M u c h A d o$. In the opening scene the Messenger, reporting on the wars, defends the actions of Benedick. He states that Benedick is "stuffed with all honourable virtues" $(\mathrm{I}, \mathrm{i}, 57-8) .{ }^{11}$ As he speaks, he assumes there is only one interpretation of "stuffed." At least, so he would wish it. But Beatrice easily converts the assertion and comments that Benedick is indeed a "stuffed man" $(\mathrm{I}, \mathrm{i}, 59)$ or a dummy. Later in the play, this very same word turns back upon Beatrice in an exchange with Margaret. Asked to smell certain perfumed gloves, Beatrice comments, "I am stuffed ..."(III,iv,64). She has a cold. While she has limited a word to a single definition, the word refuses to remain static. Margaret puns on stuffed: "A maid and stuffed . . ." (III,iv,65). One of several interpretations is that this supposed maid is pregnant. The single definition relied upon by Beatrice to express a single fact has come up against another definition. Beatrice has had her own trick played back on her and she doesn't like it. What the pun forces us to do is to handle several possible meanings of a word simultaneously. What this play does is to take the effect of the pun on our minds and expand it onto the larger stage. There is always another interpretation available, and it is usually just as valid.12

Consider, for example, Shakespeare's treatment of the windowscene deception that Borachio offers to the evil-loving Don John. According to Borachio, it is a scheme "to misuse the prince, to vex Claudio, to undo Hero and kill Leonato . . ." (II,ii,28-30). His method is deception and his purpose is evil. Yet in the preceding scene the action suggested the opposite idea about deception, an idea that may be summarized in Hero's phrase "honest slanders" (III,i,84). In that scene, Don Pedro, a good prince to balance a wicked prince, puts in operation the famous ploy to get Beatrice and Benedick together. Don Pedro comments to his fellow plotters about his device of deception: 
I will teach you how to humour your cousin, that she shall fall in love with Benedick; and I, with your two helps, will so practise on Benedick that, in despite of his quick wit and his queasy stomach, he shall fall in love with Beatrice. (II,i,395-399)

In one case "practise" is put in motion to destroy an "intended wedding," in the other, to bring one about. The means itself, deception, or "practise," as both princes term it, affects us in contradictory ways. It is a social good and a social evil. The audience cannot insist on one interpretation of this activity, just as Beatrice could not keep one meaning for "stuffed," without denying part of its experience of the play.

The function of disguise is closely related to the operation of deception in Much Ado. Like deception, which usually includes disguise as a device, it can be said to be socially destructive. In the play, its worst manifestation is Margaret's playing of Hero in "Hero's garments" to deceive Don Pedro and Claudio. Because of her actions, Claudio rejects Hero at the altar. Yet, it is through disguise, Don Pedro playing the role of Claudio at the revels, that Claudio first wins Hero. It is through a combination of the Friar's deception, his idea that Hero should continue to be given out as dead until her name was cleared, and the theatrical device of disguising Hero as her cousin that the proper comic resolution of marriage is achieved. Thus, as he presents deception, the dramatist presents disguise. While obviously the audience recognizes when deception or disguise is employed for creative or destructive ends in the dramatic action, it cannot formulate a unitary judgment about those elements as abstractions as it can, for example, in Volpone, where deception and disguise are wicked in themselves.

There is much in Shakespeare's works and in human experience to support the idea that appearances are deceiving. In Much $A d o$ it seems to Claudio that he was betrayed by Hero; appearances deceived him. When Claudio denounces Hero in the church, he asserts that appearances deceive. Of her he states:

... Would you not swear,

All you that see her, that she were a maid,

By these exterior shows? But she is none. (IV,i,39-4l)

Appearances do deceive, but not now, we may want to warn Claudio. In this case appearance is a mirror image of the truth. This argument is made explicit by the Friar who later schemes the happy ending. As M. C. Bradbrook notes, "[The Friar] takes as sure testimony what to Claudio had been hideous 'seeming." "13 He trusts Hero because of her appearance: 
By noting of the lady I have mark'd A thousand blushing apparitions

To start into her face, a thousand innocent shames

In angel whiteness beat away those blushes;

And in her eye there hath appear'd a fire,

To burn the errors that these princes hold

Against her maiden truth. . . . (IV,i,160-166)

The audience is left with contradictory alternatives: appearances deceive and do not deceive.

In a more complex way the audience senses the same duality in the Beatrice-Benedick plot. To say that they are duped into loving one another by false representations or appearances is surely insufficient. More to the point is the notion that the plotters, creating appearances, spoke the truth about the artificially masked emotions of the pair. Here, appearances and deceptions present truth. Conversely, the dislike for each other voiced by Beatrice and Benedick is indeed deception.

Similar effects are created briefly in the moral sphere by the comic instructions of Dogberry and Verges (III,iii) to the Watch. Take Dogberry's and Verges' comments in the abstract and they appear good moral generalizations. Be glad when "you are rid of a knave." Don't meddle with false men, because "they that touch pitch will be defiled." It is good to be "merciful." They also tell the Watch that its responsibility is towards "the prince's subjects" and that the Watch should not make noise in the streets. In abstract the audience can agree with such statements; but what they come to mean is something else. To be "rid of a knave" means ignore anyone who will not "stand when he is bidden." In other words, don't do your job. If a man is charged in the prince's name and doesn't answer, he's not the prince's subject and thus not the responsibility of the Watch. It is, of course, a rhetorical cover for cowardice. Not to meddle with false men means to ignore thieves. Be silent in the street means sleep rather than watch. Mercy, finally, means let the thief escape. This is hardly the ideal Watch. Thus the effect of this comedy reinforces the effect of other elements in the play. What seemed familiar and absolute is seen as something entirely different as well.

Turning to a major concern of Much Ado, love, we have more confusion. Love is defined in romantic terms, the play suggests. There is the story of Hero and Claudio demonstrating Marlowe's requirement for true love-love at first sight-though Claudio does try unconvincingly to deny the passion was so sudden $(\mathrm{I}, \mathbf{i}, 298$ 307). Though they lack the intensity of Romeo and Juliet, they go through the conventional romantic plot of meeting and love, 
separation caused by a world outside their circle of love, and reunion. In their language they "sigh away Sundays" for each other. But then there is Beatrice and Benedick. Love does not come at first sight. There is a likely reference to an earlier flirtation $(\mathrm{I}, \mathrm{i}, 39-42)$ between the two by Beatrice which may help explain their hostility toward each other. Society helps rather than hinders lovers-without Don Pedro they might never have come together. The language of love is a language that mocks love, insults the "beloved," threatens adultery, and espouses hate. The woman need not be submissive is the impression Hero makes. This is the "realistic" as opposed to the "romantic," as G. K. Hunter has noted.14 Another critic, more particularly concerned with love, comments: "[Much Ado] dramatizes opposed elements in Elizabethan (and in Shakespeare's) amorous thought."15 As we experience the play scene by scene, and even speech by speech, we shift continually from one kind of love to its apparent opposite.

Love is romantic or realistic, the play seems to say. But then at the end Benedick seems to be a romantic. After all he ends up saying to Beatrice: "I do love nothing in the world so well as you" $(\mathrm{IV}, \mathbf{i}, 269)$ and at her command sends a challenge to his friend Claudio. There is something "romantic" here. But then consider Claudio. When he is tricked into believing early in the play that he has lost Hero to a false Don Pedro the best retort he can muster is "Farewell, therefore Hero" (II,i,189). It is realistic to step aside when a prince is your rival. Also very practical is Claudio's desire to know if Hero is the only heir to her father before he declares his love $(\mathrm{I}, \mathrm{i}, 296)$. And perhaps it is simply realistic to accept Hero's cousin and the dowry at the close of the play. Yet, this is not what the audience wants; this is not resolution at all. For when Benedick turns romantic he is ready to kill his best friend; when Claudio turns realistic he appears weak or mercenary. The two concepts of love, though mixed in these characters, still appear to be mutually exclusive to the audience. ${ }^{16}$

By now I have entered into a discussion of character. In his treatment of this crucial part of the drama, Shakespeare offers us the familiar contradictions. Perhaps, as suggested, these contradictions do center upon the role of Claudio, and particularly upon two of his actions: his rejection of Hero at the church, and his acceptance of her supposed cousin in marriage at the conclusion. ${ }^{17}$ Usually, he is defended by reference to Renaissance attitudes and tastes. His rejection of Hero would not have seemed as cruel as it seems to us; his acceptance of another marriage partner would not grate on an Elizabethan audience accustomed to a businesslike attitude towards marriage. Yet cruelty is cruelty, especially when the audience knows Hero is innocent. An Elizabethan would also 
be aware of the kind of love a Romeo and Juliet or a Hero and Leander shared. Claudio is attractive; he is young, noble, handsome, and brave. Claudio is unattractive; he is calculating, ignoble at times, and perhaps of a cold disposition. The play makes available conflicting evidence concerning his character. This may be a fault; the character of Claudio may indeed be plot-ridden. I only suggest that in a drama that suspends contradictions before our eyes, the contradictions in the character of Claudio are just not very disturbing. Claudio is only part of the contradictory world.

Beatrice and Benedick, too, are full of contradictions. When Claudio asks Benedick in the opening scene what he thinks of Hero, Benedick admits that he has two contradictory ways of interpreting women. He comments to Claudio:

Do you question me, as an honest man should do, for my simple true judgment; or would you have me speak after my custom, as being a professed tyrant to their sex? (I,i,167-170)

If you can think of all women in two ways, you certainly can think of Beatrice in at least two. It is not sufficient to write down Benedick misogynist, nor to write down Beatrice shrew. When she commands the now loving Benedick to "Kill Claudio" she is refusing to remain categorized. She dances in our minds like a pun. Finally, there is Hero. For a romantic heroine Hero is silent, complacent, and obedient to her father's wishes. She seems to be just a bit out of step with what she is supposed to be. To a degree, she seems to force us to reevaluate the very idea of a romantic heroine.

Thus, as we continue to experience the comedy we find it more and more difficult to make absolute comments about the play. Perhaps we can turn to the minor character Antonio for some help. He brings to his brother some good news: it seems that the prince wants to marry Hero. Of course he is mistaken, but he is wise enough to judge the news by a cautious standard. They will be bad or good "as the event stamps them ..." (I,ii,6). Antonio seems to know what the audience should learn in the process of the play. In any case, the precise statement, the absolute, the generalization, all impose on a stage image of life that refuses to be fixed beneath them. Ultimately, asked about deception, disguise, noting, appearances, even mercy, I suspect we could subscribe in part to Antonio's phrase: "As the event stamps them." Preconceptions and absolutes just do not fit an almost relative world where contradictions compel us to admit that the very same action or feeling, deception or mercy for example, is and is not good. Much Ado makes us uncertain about the systems we would like to impose upon it and upon the human experience it images. 


\section{NOTES}

1. New York: Columbia University Press, 1969, p. vii. 227.

2. John Crick, "Much Ado about Nothing," Use of Englis.h, 17 (1965), 223-

3. John Russell Brown, Shakespeare and His Comedies, 2nd ed. (London: Methuen, 1962), pp. 109-123.

4. William G. McCollom, "The Role of Wit in Much Ado about Nothing," $S Q, 19,(1968), 165-74$.

5. Paul and Miriam Mueschke, "Illusion and Metamorphosis in Much Ado about Nothing," SQ 18 (1967), 53-65.

6. Angel with Horns and Other Shakespeare Lectures, ed. Graham Storey, (London: Longmans, 1961), pp. 65-81.

7. Denzell S. Smith, "The Command 'Kill Claudio' in Much Ado about Nothing," English Language Notes, 4 (1966-7), 181-3.

8. Shakespeare's Comedies (New York and London: Oxford, 1960), p. 69.

9. Evans, pp. 68-9.

10. "Much Ado about 'Nothing,"” SQ, 5 (1954), 287-295.

11. Shakespeare, The Complete Works of, ed. Hardin Craig (Glenview, Illinois: Scott, Foresman, 1951). All references are to this edition.

12. This approach derives from Norman Rabkin, Shakespeare and the Common Understanding (New York: The Free Press, 1967). Although Rabkin has little to say about Much Ado, his comments about other plays apply here as well: “. . . Shakespeare creates a universe susceptible of contradictory interpretations which are voiced by the characters in it and, more important, made equally plausible by the action (p. 10)." "Complementarity" is Rabkin's term for this kind of aesthetic vision.

13. Shakespeare and Elizabethan Poetry (London: Chatto and Windus, 1951), p. 185 .

14. Shakespeare: The Late Comedies, Writers and Their Work: No. 143 (London: Longmans, Green, 1962), p. 22.

15. David L. Stevenson, The Love-Game Comedy (New York: Columbia University Press, 1946), p. 216.

16. Rabkin does comment upon the "dualism of love" in Much Ado (p. 157).

17. For a discussion of some of the problems involved see C. T. Prouty, The Sources of "Much Ado about Nothing" (New Haven: Yale University Press, 1950) and Kirby Mill's response, "More Ado about Claudio: An Acquittal for the Slandered Groom," SQ, 3 (1952), 91-107. 